\title{
The Humanistic Approach of Public Services Implementation As An Effort to Achieve Good Governance
}

\author{
Hendrawan Prasetyo \\ Lecturer at the Putra Bangsa High School of Economics, Kebumen \\ Email: hendrawanprasetyo@yahoo.com
}

(Received: October 27-2020; revised: November 24-2020; published: December 31-2020)

\begin{abstract}
This study aims to determine public services with a humanistic approach. The problem in this research is that often public services are organized based on rigid, hierarchical, and convoluted rules, so that they seem to ignore the humanist side of the service. From this problem arises a desire to know how public services are organized through a humanistic approach so as not to appear rigid and prioritizing the human side of the community being served. The humanistic approach to public services involves three aspects, namely the role of human resources, service processes or procedures, as well as facilities and infrastructure that support public services. Respect for humans is reflected in the behavior of the apparatus towards the society it serves. The humanistic approach emphasizes mutual communication between public service officials and the people they serve. This research uses a qualitative approach. Information about public services performed by public service actors at the Population and Civil Registry Office of Kebumen Regency was extracted through observation, documentation, and in-depth interviews. In this study, the writing is focused on problems related to the implementation of public services with a humanistic approach to realizing good governance.
\end{abstract}

Keywords: good governance, humane, humanistic approach, public service.

\section{INTRODUCTION}

The realization of good governance is the hope of all people in our country. Good governance reflects the form of effective, efficient, transparent, accountable, and responsible governance. Effective governance is the implementation of government that is right on target following the established strategic planning. Efficient means that the implementation is carried out efficiently and effectively, transparent means that all policies carried out by state administrators are open, everyone can supervise directly so that they can provide an assessment of their performance on the results achieved, accountable means that government administrators are responsible for stipulated policies, as well as accountability for their performance to all citizens. (Maryam, 2016). Public services are a measure of the success of implementing tasks and measuring government performance through the bureaucracy. Public services as the main driver are also considered important by all actors from the elements of good governance. (Maryam, 2016). The application of the principles of good governance is very important in the implementation of public services to improve the performance of the state apparatus. This is because the government has designed the concept of good governance principles to increase the potential for change in the bureaucracy to realize better public services, also, the public still thinks that public services carried out by the bureaucracy must tend to be slow, unprofessional, and expensive. (Maryam, 2016). 
Hendrawan Prasetyo; A Humanistic Approach of Public Services Implementation ... $\mid 467$

One approach or paradigm to facilitate professional bureaucratic services is to use a humane approach, or what is referred to in this paper as a humanist paradigm. The humanist paradigm can be given the meaning that a person in treating others must pay attention to the human side of that person, group, or society. This means that if individuals or groups become part of the state administration (public), then in providing services, they must also pay attention to the humanist side of the society they serve. (Prasodjo, 2017)

One of the humanist paradigms in public service is the existence of effective reciprocal communication. (Prasodjo, 2017). In a humane approach is how public servants must be able to respond to all forms of service, not only from clients who have to be served and need them at that time but all citizens are part of the service itself, even if they do not need services at that time. This need can be made with information or socialization. (Ningtyas, 2017)

There are 3 (three) important elements in public services, namely 1 . Service provider organization, namely the Regional Government, 2. Service recipients (customers), namely people or communities or organizations with an interest, 3. Satisfaction is given and/or received by the service recipient (customer). Public services must always change following the development of society because society is dynamic. In this case, the government must negotiate and collaborate on various interests of the community. So that public services have the quality that is expected by the community. Public services are carried out in a series of integrated activities that are simple, open, smooth, precise, complete, reasonable, and affordable.

Humanistic public servants are considered to be responsible both for law/procedure, values, community, social and political norms. So the values in this society are also a major part of the implementation of services. Broadly speaking, it turns out that many have had a direct or indirect impact as a result of the services provided by public services. (Ningtyas, 2017). The first characteristic of humanistic public servants is that public servants must have a desire to serve the community, so this will foster a high commitment to employees that serving the public is the main form of obligation to employees of public institutions. The implementation of good public services indicates improved government management performance, on the other hand, shows a change in mindset that affects better changes in mental attitudes and behavior of government officials who are oriented towards public services. (Maryam, 2016).

The source of the power of man on basically is one of the factors that is very important within an organization, both organizations public and private, for humans who are planning to oversee implementation of activities within the organization. Where the man in question must be sufficient in number as needed and have adequate skills by the demands of the tasks in the organization. According to Handoko (2003: 233) in his book Management, Personnel and Resources Power Man said that " Source Power Humans are the people who provide energy, talent, creativity, and business efforts to the activities of the organization ."

In the context of non-profit organizations or public services, such as government organizations, the notion of human resource management in principle is not different from the notion of human resource management in the context of a business firm. According to Berman, E. M., et al. (2001) human resource management is concerned with developing policies for the effective use of human resources in organizations. In other words, all decisions that affect the relationship between individuals and organizations can be viewed as a dimension of human resource management. 


\author{
468 Jurnal Ilmiah Ilmu Administrasi Publik: Jurnal Pemikiran dan Penelitian Administrasi \\ Publik \\ Volume io Number 2, July-December 2020. Page 466-473
}

Public servant who humanistic promote value - the value of humanity, so is expected to be able to satisfy those who served in the case of this is the community. Moenir (2005: 197) states that so that the service is satisfactory to the person or group of people who are served, then the offender in the case of this officer should be able to meet the four requirements of the principal, namely: 1. The behavior is polite. With the polite manners of people feel respected and appreciated as like in a relationship of humanity with such already is a satisfaction in itself for the horse. 2. How to convey. Submission of something that relates to what is supposed to be received by the person concerned and should pay attention to the principles by the provisions that apply to avoid the delivery of the deviant. 3. Time of delivery. Delivering something results processed are precisely highly coveted every person who has the problem. 4. Hospitality. Hospitality . Only exist in the service orally either deal or no deal.

The procedure of service in the ministry of the public who put forward the approach of humanistic must meet the standards of service are good. Standard services by Kasmir (2005: 1821 ) is the basic of the basic service. Ten things should be considered to make the recipient of the service secure, convenient, and fun, among others, namely: 1. Dress up and look neat and clean. 2. Believe yourself, to be intimate and filled with smiles . 3. Greet with soft and trying to mention the name if already know one each other. 4 . Calm, polite, respectful, and diligent in listening to the attitude of the conversation. 5. Speaking with the language that is good and true.6. Passionate about serving customers and showing their abilities . 7. Do not interrupt or interrupt the conversation . 8. Able to convince customers and provide satisfaction .9. If you are unable to deal with the existing problem, ask for help. 10. If not able to serve, tell when it will be served.

In addition to the role of the source of the power of man and procedures of service appropriate standards, facilities and infrastructure in the organization of services public is also a thing that is important in supporting the ministry of the public to approach the humanistic.

The identification of the problem in this research is what is the form of public service delivery that refers to the principles of good governance?

What is the form of public service with a humanistic approach carried out by public service agencies as an effort to realize good governance?

\title{
METHOD
}

This type of research is qualitative research. With the qualitative approach used in this study, trying to get as complete as possible information about public services carried out by public service actors in the Department of Population and Civil Registration of Kebumen Regency which was explored through in-depth interviews with informants consisting of employees of the Department of Population and Civil Registration. Kebumen Regency and the public who use public services at the Population and Civil Registry Office of Kebumen Regency. The data collected came from interview manuscripts, field notes, personal documents, memo notes, and other official documents. The focus of this research is the Department of Population and Civil Registration of Kebumen Regency. Retrieval of data sources in this study using a "purpose sampling" technique with informants consisting of employees of the Department of Population 
Hendrawan Prasetyo; A Humanistic Approach of Public Services Implementation ... $\mid 469$

and Civil Registration of Kebumen Regency and community service users at the Department of Population and Civil Registration of Kebumen Regency who were randomly selected.

The data collection techniques used will complement in obtaining primary and secondary data, observation and interviews are used to capture primary data relating to how the humanistic approach in public services can be applied to existing public service agencies, Gombong District, Kebumen Regency to achieve good governance, while the study documentation is used to collect secondary data that can be lifted from various documentation about the form of public services with a humanistic approach organized by the public service agency under study.

The stages in data collection in this study consist of the orientation stage, the exploration stage, and the member check stage. At the stage of orientation, the researchers carried out a presurvey to the location to be studied. In this study, the pre-survey was carried out at the Department of Population and Civil Registration of Kebumen Regency. Then the researcher also conducted a documentation study and literature to see and record the data needed in this study. At the exploration stage, it is the stage of collecting data at the research site, by conducting interviews with related elements, with interview guidelines that have been provided by researchers, and making indirect observations about the actual conditions and making direct observations about the form of public services that use the humanistic approach at the Department of Population and Civil Registration of Kebumen Regency.

\section{RESULTS AND DISCUSSION}

The image of public services is often not following public expectations. Public services are often seen as unfriendly activities, take a long time, are complicated or convoluted, are not easy, and often many third parties take part in smoothing services through intermediary brokers. This image is of course a problem in itself, especially for public service agencies which in this study were the Department of Population and Civil Registration of Kebumen Regency. This problem often raises various complaints in the community. Responding to problems and complaints that arise in the community, the Department of Population and Civil Registration of Kebumen Regency has the right solution in public services, namely by carrying out: innovation, collaboration, and decentralization in the services provided.

The Department of Population and Civil Registration of Kebumen Regency organizes public services with a service motto: " Service wholeheartedly and to make the community happy". The service motto is of course a service manifestation with a humanistic approach. The implementation of public services must have a high sense of social so that the work pattern is always oriented towards the interests and needs of the public being served (customer-oriented), which of course is more humanistic and dynamic. (Prasodjo: 2017). The humanistic approach in services provided by the Department of Population and Civil Registration of Kebumen Regency is reflected in the chants in the service apparatus, namely "Dukcapil BISA". CAN stands for Work, Innovative and Initiative, Patience and Smile, Adaptive.

Based on observations made by researchers and with the support of documents obtained from the Department of Population and Civil Registration of Kebumen Regency, information was obtained that the humanistic approach in service is shown in the completeness and convenience of facilities and infrastructure in the Department of Population and Civil Registration of Kebumen Regency. Among them are the large and proper parking spaces, parks, clean and adequate toilets, 


\section{0 | Jurnal Ilmiah Ilmu Administrasi Publik: Jurnal Pemikiran dan Penelitian Administrasi Publik \\ Volume 10 Number 2, July-December 2020. Page 466-473}

prayer rooms, and reading corners that allow people to take the time to read interesting books while waiting for services. There is also a CCTV monitoring area and a cellphone charger provided for the public. From the results of observations, information was obtained that the other supporting facilities and infrastructure for public services in the Department of Population and Civil Registration of Kebumen Regency include the presence of a service queue machine. This service queue machine adds to the convenience of the community when queuing. If previously people complained about long queues and uncomfortable places, this is no longer the case. Through a humanistic approach that is oriented towards respecting human values, even in line, there are very adequate facilities, spacious air-conditioned rooms, and a queuing machine. Also, there are quite a lot of service counters that make it easier for the community. For handling problematic data, there is also a special service queue machine. Based on observations made by researchers, information was obtained that there are also lactation room facilities for nursing mothers and children's play areas. This allows convenience and comfort for visitors/people who need services. The availability of adequate facilities and infrastructure at the Department of Population and Civil Registration of Kebumen Regency shows evidence that public services are organized using a humanistic approach. Public services are provided for all people without exception. For people with special needs who need services at the Department of Population and Civil Registration of Kebumen Regency, there are special facilities for people with disabilities in the form of push ladders, wheelchairs, and special bathrooms/toilets.

Public service with a humanistic approach is a form of service that highly appreciates the people it serves. One of the forms of appreciation for the community served is the certainty in service which includes certainty regarding the timeliness of service. The certainty of the appropriate service time has proof of achievement that the service is appropriate and on time is based on the KPI (Indicator of Performance Achievement) Disdukcapil. That the realization of the target for achieving Disdukcapil documents reached an average of 98\% in RENJA 2019. Public services with a humanistic approach emphasize aspects of public services that prioritize the human side. One of them is that when people do not need services, it is the responsibility of public service providers to provide socialization and information needed by the community. This socialization and information can be channeled through various media. Socialization and information are conveyed through social media Facebook, Instagram, WA, and the website. Public services with a humanistic approach are implemented in a series of integrated activities that are simple, open, smooth, precise, complete, reasonable, and affordable. This is also carried out by the public service agency of the Population and Civil Registry Service (Disdidukcapil) of Kebumen Regency. Employees at Disdukcapil Kebumen Regency are responsive in providing services to the community. Responsiveness in serving is a form of respect for the people it serves. Humanist attitudes through a humanistic approach in public services can be seen from how officers serve the community. Values in society are a major part of the implementation of public services provided, service officers are always friendly, there are improvements in facilities and infrastructure so that they are more adequate and the community will feel comfortable in getting public services. Service poses or service procedures that use a humanistic approach emphasize public services with procedures that make it easier for the community, without exception for people with special needs/disabilities. Disdukcapil Kebumen provides services with media k 's facilities needed for people with special needs. Serving society with a humane approach takes 
into account the thoughts, feelings, and body language of the people being served. This will create optimal public services. For residents with special needs who will take care of population documents, this is prioritized. And if it has to be in body language, at the Department of Population and Civil Registration of Kebumen Regency some employees take part in training and workshops to handle people with disabilities or special needs by using sign language.

The humanistic approach in implementing public services creates various innovations in public services at the Department of Population and Civil Registration of Kebumen Regency. The forms of public service innovation are:

1. Baladeva Program Born or babies born with a birth certificate in collaboration with both public and private hospitals and health centers.

2. The Catapel-17 program is an innovation intended for mandatory ID cards for beginners or those aged 17 years. The Catapel-17 program is an innovation from the Department of Population and Civil Registration of Kebumen Regency which is intended for mandatory ID cards for beginners or at 17 years of age, where at the age of 17, they immediately receive an electronic KTP as a birthday gift from the Kebumen Regency Government. The background of this program is that residents who are 17 years of age or already married or have been married are required to have an electronic KTP. considering that when they entered the age of 17, there were still many who did not have electronic KTPs, so that with the KeTaPel-17 program, residents who were 17 years old immediately had electronic KTPs. This program aims to create an orderly population administration. The benefits of this program are that residents aged 17 years have electronic ID cards, have an orderly population administration, reduce school children who are not allowed to attend a school, or skip school to take care of electronic KTPs.

3. ASN Pen Program (Package For ASN Retired Services)

4. Paksaur Program (One Time Management Package)

5. Banner Kiosk Innovation Program or Population Administration Services in Villages or Kelurahan

6. Online Service Program through the website: http://pelayananependempat.kebumenkab.go.id/

7. Pick up the ball to villages and schools.

8. The service door to door for difable community and mental disorder/physical.

\section{CONCLUSION}

Based on the results of the research and analysis that have been described, the following conclusions can be drawn:

The humanistic approach in public services is an approach used in public services that prioritize humanist/humanitarian values. In this study, the service approach carried out at the Department of Population and Civil Registry of Kebumen Regency is focused on the extent to which respect for humans is carried out for the implementation of good public services. This humane approach is used to facilitate public services. From the results of the research conducted, information was obtained that the humanistic approach in public services at the Department of Population and Civil Registry of Kebumen Regency involves three aspects in the implementation of public services, namely: 


\section{2 | Jurnal Ilmiah Ilmu Administrasi Publik: Jurnal Pemikiran dan Penelitian Administrasi Publik \\ Volume 10 Number 2, July-December 2020. Page 466-473}

1. The role of human resources is shown through the attitude of the public service apparatus in serving the community.

2. Service processes/mechanisms/procedures that are carried out in the delivery of public services.

3. Facilities and infrastructure that support public services.

Public services with a humanistic approach are implemented in a series of integrated activities that are simple, open, smooth, precise, complete, reasonable, and affordable. From the results of research conducted at the Department of Population and Civil Registry (Disdidukcapil) Kebumen Regency, this is also carried out by these public service agencies.

Humanist attitudes through a humanistic approach in public services can be seen from how officers serve the community. The values in society are a major part of the implementation of public services provided. In this study, the Department of Population and Civil Registry of Kebumen Regency tries to always prioritize the humanist side in providing services. Service officers are always friendly, there are improvements in facilities and infrastructure so that they are more adequate and people feel comfortable in getting public services.

There are three main principles for realizing humanistic-based public services, namely: Public servants must have a desire to serve the community, public servants must respond to all forms of service not only from clients but all citizens, accountability of public services is multiaspect (must be responsible for both law/procedure, values, community, social and political norms). Through this research, this principle has been fulfilled by the Kebumen District Education and Civil Registry Office. Service poses or service procedures that use a humanistic approach emphasize public services with procedures that make it easier for the community, without exception for people with special needs/disabilities. The Disdukcapil of Kebumen Regency provides services by providing the facilities needed for all communities, including those with special needs.

To implement good public services for the realization of good governance, the humanistic approach is the right approach used by public service agencies. With this approach, services not only focus on rigid procedures through Standard Operating Procedures (SOPs), but values in society also become a major part of the implementation of public services provided.

The humanistic approach to public services will encourage public service agencies to continue to make efforts to improve services because problems that arise in public services that are communicated to the public through a humane approach will bring up various alternative solutions in the form of public service innovation, service collaboration with other agencies, and decentralization. the three of them will encourage the realization of better public services.

\section{REFERENCES}

Dunn, William N. ( 2003 ). Public Policy Analysis. Yogyakarta: Gadjah Mada University Press. Maryam, Neneng Siti (2016). Journal of Political Science and Communication Volume VI No. 1 / June 
Prasodjo, Tunggul, ( 2017 ). Humanist Paradigm in Public Service, Scientific Journal of Public Administration, Vol. 7, No.1.

SEA-Practical Application of Science Volume III, Issue 1 (7), 2015, Good Governance: Normative VS Descriptive Dimension

Sinambela, Lijan P. ( 2006 ) . Public Service Reform. PT Bumi Aksara: Jakarta

Kepmenpan Number 63 of 2004 concerning General Guidelines. Public Service Delivery

Winarno, Budi. ( 2007 ) . Public Policy: Theory and Process. Yogyakarta: Med Press (Member of IKAPI).

Baharuddin and Moh. Makin. ( 2007 ). Humanistic Education (Concepts, Theory, and Applications of Praxis in the World of Education) Yogyakarta Ar-Ruz Media.

Ningtyas, Trimurti, ( 2017 ). Humanistic Based Public Services For Successful Bureaucratic Reformation.

Law No. 25 of 2009 concerning Public Services

MENPAN Decree Number 63 the Year 2004

Baharuddin, \& Moh. Makin. (2007). Humanistic Education (Concepts, Theory, and Applications of Praxis in the World of Education). Yogyakarta: Ar-Ruzz Media.

Handoko, T.Hani,2003, Manajemen Personalia dan Sumber Daya Manusia, Yogyakarta, BPFE Yogyakarta

Moenir, 2005, Manajemen Pelayanan Umum di Indonesia, Bumi Aksara, Jakarta.

Berman, E. M., et al. (2001). Human Resource Management in Public Service: Paradoxes, Processes, and Problems. London: Sage Publications. Inc.

Mahmudi. 2005. Manajemen Kinerja Sektor Publik. Yogyakarta: UPP AMP YKPN

Kasmir. 2005. Pemasaran Jasa. Jakarta: Graya Grafindo Persada 